Article

\title{
Insights into the Allergenic Potential of the Edible Yellow Mealworm (Tenebrio molitor)
}

\author{
Annick Barre 1이 ${ }^{1}$ Carole Pichereaux ${ }^{2}$, Esmeralda Velazquez ${ }^{1}$, Agathe Maudouit ${ }^{1}$, \\ Mathias Simplicien ${ }^{1} \oplus$, Lorna Garnier ${ }^{3}$, Françoise Bienvenu ${ }^{3}$, Jacques Bienvenu ${ }^{3}$, \\ Odile Burlet-Schiltz ${ }^{2}$, Cédric Auriol ${ }^{4}$, Hervé Benoist ${ }^{1}$ and Pierre Rougé ${ }^{1, *}$ \\ 1 UMR 152 Pharmacochimie et Biologie pour le Développement, Université Paul Sabatier, Institut de \\ Recherche et Développement, Faculté de Pharmacie, 35 Chemin des Maraîchers, 31062 Toulouse, France; \\ annick.barre@univ-tlse3.fr (A.B.); esmeralda.velazquez@univ-tlse3.fr (E.V.); \\ agathe.maudouit@gmail.com (A.M.); simplicien.mathias@gmail.com (M.S.); herve.benoist@ird.fr (H.B.) \\ 2 Institut de Pharmacologie et Biologie Structurale, IPBS, Université de Toulouse, CNRS, UPS, 31077 Toulouse, \\ France; Carole.Pichereaux@ipbs.fr (C.P.); Odile.Schiltz@ipbs.fr (O.B.-S.) \\ 3 Laboratoire d'Immunologie, Hospices Civils de Lyon, Centre Hospitalier Lyon Sud, 165 Chemin du Grand \\ Revoyet, 69495 Pierre-Bénite, France; lorna.garnier@chu-lyon.fr (L.G.); francoise.bienvenu@chu-lyon.fr (F.B.); \\ jacques.bienvenu@chu-lyon.fr (J.B.) \\ 4 Micronutris, 6 Rue de Partanaïs, 31650 Saint-Orens-de-Gameville, France; contact@micronutris.fr \\ * Correspondence: pierre.rouge@free.fr; Tel.: +33-069-5520851
}

Received: 9 August 2019; Accepted: 25 September 2019; Published: 18 October 2019

check for updates

\begin{abstract}
The edible yellow mealworm (Tenebrio molitor), contains an extremely diverse panel of soluble proteins, including proteins with structural functions such as muscle proteins, as well as proteins involved in metabolic functions such as enzymes. Most of these proteins display a more or less pronounced allergenic character toward previously sensitized people, especially people allergic to shrimps and other shellfish. A mass spectrometry approach following the separation of a mealworm protein, extracted by sodiumdodecyl sulfate-polyacrylamide gel electrophoresis, allowed us to identify up to 106 distinct protein fractions including molecules with structural and functional functions, susceptible to developing an allergenic potential due to the possibility of immunoglobulin E-binding cross-reactions with their counterparts occurring in shellfish. In this respect, most of the sera from people allergic to shrimps reacted with the mealworm protein extract in Western blot experiments. Moreover, the potential mealworm allergens triggered the in vitro degranulation of rat leukemic basophils transfected with the human high-affinity IgE receptor (FceRI), upon sensitization by the IgE-containing sera from people allergic to shrimps and other shellfish foods. Owing to the large repertoire of IgE-binding cross-reacting allergens the yellow mealworm shares with other phylogenetically-related groups of arthropods, it would seem prudent to inform the consumers, especially those allergic to shellfish, by appropriate labeling on edible mealworm packages about the potential risk of developing an allergic reaction.
\end{abstract}

Keywords: allergen; allergenicity; immunoglobulin E cross-reacting allergens; yellow mealworm; Tenebrio molitor; arthropods; food allergy; in vitro degranulation test; mass spectrometry

\section{Introduction}

Promoting the use of alternative sources of proteins to cover the food needs of the steadily increasing world population has now become a major concern for the future. Additionally, new sources of proteins are required to be produced in accordance with the energetic and environmental constraints, e.g., with an environmentally accepable carbon footprint [1-8]. In this respect, the industrial farming of edible insects and the production of insect proteins has reached a sufficient degree of improvement to 
meet most of these environmental requirements [9-11]. Beyond their nutritional value, insect proteins produced from industrial farming meet the toxicological and microbiological safety requirements allowing them to be available as safe food products [12-16]. However, due to the phylogenetic relationship between insects and other arthropods, there is some allergological concern since an allergic reaction may occur in consumers suffering from a shrimp allergy [17-23]. In agreement, hypersensitivity reactions due to the consumption of edible insects have been reported, especially in people living in countries where edible insects are traditionally consumed for a long time [24-31]. In addition, tropomyosin and arginine-kinase have been identified as the major allergens of insects [32-36]. More recent investigations have pointed out the risk of allergic reactions associated with the consumption of yellow mealworm (Tenebrio molitor), a commonly farmed edible insect in European countries, for people allergic to shrimps [37-39]. Different IgE-binding cross-reacting allergens including tropomyosin, $\alpha$-amylase, arginine kinase, and hexamerin, have been identified as the major offending food allergens, especially of the yellow mealworm [40-42]. However, owing to the extreme complexity of the insect protein content, the list of IgE-binding cross-reacting allergens occurring in mealworm most probably remains incomplete and the present work was aimed at providing a more exhaustive list of potential immunoglobulin E (IgE)-binding cross-reacting allergens susceptible to occur in mealworm.

\section{Experimental Procedure}

\subsection{Yellow Mealworm Protein Extract}

A total of $150 \mathrm{mg}$ of yellow mealworm flour (Micronutris) was suspended in $850 \mu \mathrm{L}$ of tris-buffered saline (Tris $20 \mathrm{mM}, \mathrm{NaCl} 130 \mathrm{mM}$, ethylenediaminetetraacetic acid $2 \mathrm{mM}, \mathrm{pH} 7.4$ ) and homogenized by two grinding steps of $40 \mathrm{~s}$ each with steel pellets in a Fast Prep-24 homogenizer (MP Biomedicals, Illkirch, France). The resulting slurry was centrifuged at $13,000 \mathrm{rpm}$ for $10 \mathrm{~min}$ at $4{ }^{\circ} \mathrm{C}$. The supernatant fraction was carefully collected while avoiding the floating lipid layer and stored at $-20^{\circ} \mathrm{C}$ until used. The protein content in the mealworm protein extract was estimated by the bicinchoninic method kit (Pierce) [43], using bovine serum albumin (Sigma, Saint Quentin Fallavier, France) as a standard.

\subsection{Patient Sera}

Well documented blood samples with various specific IgE content were drawn after receiving the informed consent of 21 patients experiencing shrimp anaphylaxis. Their reactivity towards the yellow mealworm extract was checked in dot-plot experiments and Western blot analyses. Dust mite allergic patient sera $(n=13)$ were also checked for IgE-reactivity towards the mealworm extract. A new table indicating for 21 sera from shrimp-allergic patients and 13 sera from dust mite allergic patients (Table A1), the measured specific IgE contents (express as $\mathrm{kU} \cdot \mathrm{L}^{-1}$ ) and cross-reactivities, is proposed as an Annex to the text.

\subsection{Dot-Blot Screening}

The shrimp-allergic patient sera were screened for their IgE-reactivity towards the yellow mealworm protein extract using a dot-blot technique. The mealworm protein extract $(1 \mu \mathrm{L})$ was spotted on a nitrocellulose membrane at increasing protein concentrations $\left(1,5,10,15\right.$, and $\left.20 \mu \mathrm{g} \cdot \mathrm{mL}^{-1}\right)$, and checked for IgE-binding reactivity with the shrimp-allergic patient sera using goat horseradish peroxydase (HRP)-labelled antihuman IgE (Invitrogen) as a probe, as described in $\S 4.3$ for Western blot experiments. Dust mite allergic patient sera $(n=13)$ were also checked for IgE-reactivity towards the mealworm extract but only two of them gave a readily positive result in dot-blot experiments.

\subsection{SDS-PAGE and Western Blot Experiments}

SDS-PAGE was performed in $12.5 \%$ acrylamide gels and protein fractions were stained with Coomassie blue R250 (BioRad, Marnes-la-Coquette, France) [44]. Western blot experiments were performed after a semi-dry transfer of the protein fractions separated by SDS-PAGE on nitrocellulose 
sheets (Amersham, Les Ulis, France). After an overnnight incubation in 10 mM PBS (pH 7.4) containing $5 \%(v / v)$ skimmed milk, membranes were soaked in properly 1:10 diluted shrimp-allergic patient sera and incubated in a moist chamber for $2 \mathrm{~h}$ at room temperature. After three washings of $10 \mathrm{~min}$ each with the same buffer, membranes were soaked and incubated for $1 \mathrm{~h}$ under gentle stirring, in goat HRP-labelled antihuman IgE (Invitrogen) diluted 1:1500. Following three washings of 10 min each with buffer, the immunolabelled protein fractions were revealed using the SuperSignal West Dura substrate (ThermoScientific, Illkirch, France) by chemiluminescence.

Bi-dimensional SDS-PAGE was performed using strips with pH 3.0-10.0 (ZOOM Strip pH 3-10NL-Novex, Illikirch, France). The yellow mealworm protein extract was mixed with the rehydration solution BioRad (CHAPS 4\%, 0.2\% BioLyte 1X, urea 8M, DTT $20 \mathrm{mM}$ ), added to a final volume of $155 \mathrm{~mL} /$ strip, and strips were rehydrated overnight in the scelled ZOOM IPGRunner cassettes (Thermo Fisher Scientific, Illkirch, France). The IEF migration was conducted consecutively at $175 \mathrm{~V}$ (15 min), up to $2000 \mathrm{~V}$ ( $45 \mathrm{~min}$ ), and at $2000 \mathrm{~V}$ ( $45 \mathrm{~min}$ ). Strips were incubated for $15 \mathrm{~min}$ in the reducing solution (625 $\mu \mathrm{L} 4$ X NuPage LDS Sample Buffer, $2075 \mu \mathrm{L}$ dist. water, $300 \mu \mathrm{L}$ NuPage Sample Reducing Agent 10X), and further incubated in the alkylation solution ( $300 \mu \mathrm{L} 4 \mathrm{X}$ NuPage LDS Sample Buffer, $2700 \mu \mathrm{L}$ dist. water, $70 \mathrm{mg}$ iodoacetamide) for an additional $15 \mathrm{~min}$. Strips were then introduced at the top of a $12.5 \%$ acrylamide SDS-PAGE gel, covered with $0.5 \%(w / v)$ molten agarose, and run at $200 \mathrm{~V} / 30 \mathrm{~mA}$ using a Tris-glycine running buffer ( $\mathrm{pH}$ 8.3). Protein spots were stained with Coomassie blue R250 (BioRad, Marnes-la-Coquette, France).

\subsection{Degranulation Test}

Degranulation of rat leukemic cells RBL SX38 [45], transfected with the high-affinity human FcERI receptor, in the presence of the meaworm protein extract, was performed in 96-well plates on RBL SX38 cells $\left(2.10^{5}\right.$ cells) cultured in minimum essential medium (MEM) Gibco (Thermo Fisher Scientific, Illkirch, France) containing $10 \%(v / v)$ foetal calf serum, for 2 days at $37^{\circ} \mathrm{C}$. Cells were then cultured in the MEM medium containing 2\% $(v / v)$ sample sera from different shrimp-allergic patients (diluted 1:40, $v / v$ ), for 2 days at $37^{\circ} \mathrm{C}$. Cells were washed two times with tyrode buffer (Sigma, Saint-Quentin Fallavier, France and incubated for $45 \mathrm{~min}$ at $37^{\circ} \mathrm{C}$ in tyrode/D2O $(1: 1, v / v)$ buffer containing $1.0 \mu \mathrm{L}$ of mealworm protein extract. Cells were further incubated for $90 \mathrm{~min}$ at $37^{\circ} \mathrm{C}$ in $50 \mu \mathrm{L}$ of $0.05 \mathrm{M}$ citrate buffer (pH 4.5) containing $1.3 \mathrm{mg} / \mathrm{mL}$ of $p$-nitrophenyl N-acetyl- $\beta$-D-glucosaminide (Sigma, Saint-Quentin Fallavier, France) as a chromogenic substrate for the hexosaminidase. The color reaction was stopped by adding $100 \mu \mathrm{L}$ of $0.4 \mathrm{M}$ glycine buffer ( $\mathrm{pH}$ 10.7) and the absorbance was spectrophotometrically measured at $410 \mathrm{~nm}$. Degranulation obtained under similar conditions by probing a shrimp protein extract, was used as a sample for the $100 \%$ degranulation value.

\subsection{Digestion and Nano-LC-MS/MS Analysis}

Proteome samples were reduced and alkylated using equilibration buffers containing dithiothreitol and iodoacetamide, and loaded onto a 12\% SDS-polyacrylamide gel. After Instant Blue (Invitrogen) staining of the gel, bands were excised and digested by the addition of $60 \mu \mathrm{L}$ of a solution of modified trypsin in $25 \mathrm{mM} \mathrm{NH}_{4} \mathrm{HCO}_{3}(10 \mathrm{ng} / \mu \mathrm{L}$, sequence grade, Promega, Charbonnières, France). The mixture was incubated at $37{ }^{\circ} \mathrm{C}$ overnight. The peptides mixtures were analyzed by nano-LC-MS/MS (Liquid chromatography-mass spectrometry/Mass spectrometry) using nanoRS UHPLC system (a nanoliter-range ultra high performance liquid chromatography, Dionex, Amsterdam, The Netherlands) coupled to an LTQ-Orbitrap Velos mass spectrometer (Thermo Fisher Scientific, Bremen, Germany). Five microliters of sample were loaded on a C18 precolumn (300 $\mu \mathrm{m}$ inner diameter $\times 5 \mathrm{~mm}$, Dionex) at $20 \mu \mathrm{L} / \mathrm{min}$ in $5 \%$ acetonitrile, $0.05 \%$ trifluoroacetic acid. After 5 min desalting, the precolumn was switched in line with the analytical C18 column $(75 \mu \mathrm{m}$ inner diameter $\times 15 \mathrm{~cm}$; in-house packed) equilibrated in $95 \%$ solvent A ( $5 \%$ acetonitrile, $0.2 \%$ formic acid) and $5 \%$ solvent B ( $80 \%$ acetonitrile, $0.2 \%$ formic acid). Peptides were eluted using a $5 \%-50 \%$ gradient of solvent B during $105 \mathrm{~min}$ at a $300 \mathrm{~nL} \mathrm{~min}^{-1}$ flow rate. The LTQ-Orbitrap was operated in 
data-dependent acquisition mode with the Xcalibur software. Survey scan MS spectra were acquired in the Orbitrap on the 300-2000 $\mathrm{m} / \mathrm{z}$ range with the resolution set to a value of 60,000 . The 20 most intense ions per survey scan were selected for collision-induced dissociation (CID) fragmentation, and the resulting fragments were analyzed in the linear trap (LTQ). Dynamic exclusion was used within $60 \mathrm{~s}$ to prevent repetitive selection of the same peptide.

The Mascot Daemon software (version 2.5, Matrix Science, London, UK) was used to perform database searches in batch mode with all the raw files acquired on each sample. To automatically extract peak lists from Xcalibur raw files, the Extract_msn.exe macro provided with Xcalibur (version 2.2 SP1.48, Thermo Fisher Scientific, Illkirch, France) was used through the Mascot Daemon interface. The following parameters were set for creation of the peak lists: parent ions in the mass range 400-4500, no grouping of MS/MS scans, and threshold at 1000. A peak list was created for each analyzed fraction (i.e., gel slice), and individual Mascot searches were performed for each fraction. Data were searched against all entries in the Tenebrionidae 20170606 protein database (22,376 sequences; 10,097,372 residues). Oxidation of methionine and carbamidomethylation of cysteine were set as variable modifications for all Mascot searches. Specificity of trypsin digestion was set for cleavage after Lys or Arg except before Pro, and one missed trypsin cleavage site was allowed. The mass tolerances in MS and MS/MS were set to $5 \mathrm{ppm}$ and $0.8 \mathrm{Da}$, respectively, and the instrument setting was specified as "ESI-Trap". Mascot results were parsed and validated with an in-house software called Proline (ProFi Proteomics, France). The target-decoy database search allowed us to control and estimate the false positive identification rate of our study, and the final catalogue of proteins presented an estimated false discovery rate (FDR) below $1 \%$ for peptides and proteins.

\subsection{Bioinformatics}

Multiple amino acid sequence alignments were carried out with CLUSTAL-X [46] using the stuctural Risler's matrix for homologous residues [47].

Except for the three-dimensional structures of apoL-III of Locusta migratoria (protein data bank (PDB) code 1AEP [48] and 1LS4 [49]) and Manduca sexta (PDB code 1EQ1) [50], and the $12 \mathrm{kDa}$ hemolyph protein of Tenebrio molitor (PDB code 1C3Z) [51], which are available at the Protein Data Bank (PDB), the three-dimensional models of other apoL-III, $12 \mathrm{kDa}$ HLP (hemolymph protein) and larval cuticle proteins were built by homology modeling with the YASARA Structure program [52]. The three-dimensional structure of the Locusta migratoria apoL-III (PDB code 1AEP) was used as a template to build up to 3 different models for each of the modelled apoL-IIIs. Finally, hybrid models of the apoL-III of Acheta domesticus (house cricket), Bombyx mori (silkworm), Galleria mellonella (greater wax moth), Musca domestica (housefly), and Schistocerca americana (American grasshopper) were built up from the different previous models. Similarly, the three-dimensional structures of odorant binding proteins (OBP) from Apis mellifera (PDB code 3S0D) [53], Anopheles gambiae (PDB code 3R1P) [54], AtraPBP1 from Amyelois transtyella (PDB code 4INW) [55], Antheraea polyphemus PBP1 (PDB code 2JPO) [56], Bombyx mori GOBP2 (PDB code 2WCJ) [57], chemosensory protein from Mamestra brassicae (PDB code 1N8V) [58], and chemosensory protein 1 from Bombyx mori (PDB code 2JNT) [59]), were used as templates for the building of the $12 \mathrm{kDa}$ HLP models. Finally, hybrid models of the $12 \mathrm{kDa}$ HLP (hemolymph protein) of Manduca sexta (Carolina sphinx moth), Rhynchophorus ferrugineus (red palm weevil), and Tenebrio molitor (yellow mealworm) were built up from the different previous models. A single protein template, the crystal structure of p53 epitope-scaffold of a cysteine protease in complex with human MDM2 protein (5SWK), available at the PDB, was used for building the 3D-model for the larval cuticle proteins (LCP) of Tenebrio molitor, Bombyx mori, Locusta migratoria, Musca domestica, and Tribolium castaneum (red flour beetle). PROCHECK [60], Atomic Non-Local Environment Assessment (ANOLEA) [61], and the calculated QMEAN scores [62,63], were used to assess the geometric and thermodynamic qualities of the three-dimensional models. Using ANOLEA to evaluate the models, only a few residues of the different models exhibited an energy over the threshold value. Both residues 
are mainly located in the loop regions connecting the $\alpha$-helices or $\beta$-sheets in the models. The calculated QMEAN6 score of all of the models gave values $>0.5$.

The ConSurf server was used to discriminate between conserved and variable regions in the allergen models [64]. Molecular cartoons were drawn with YASARA [52] and Chimera [65].

\section{Results}

\subsection{Dot-Blot Screening of Shrimp-Allergic Patient Sera Towards a Yellow Mealworm Protein Extract}

A dot-blot screening of a number of sera from patients allergic to the shrimp $(n=21)$ and the dust mite Dermatophagoides peteronyssinus $(n=13)$ toward a mealworm protein extract immobilized on nitrocellulose sheet resulted in positive responses for almost all (20/21) of the checked shrimp sera (Figure 1), whereas a very few dust mite sera reacted positively (2/13). However, depending on the checked shrimp sera, large discrepancies with respect to the IgE-binding capacity were noticed between strongly and more weakly IgE-reacting serum samples.

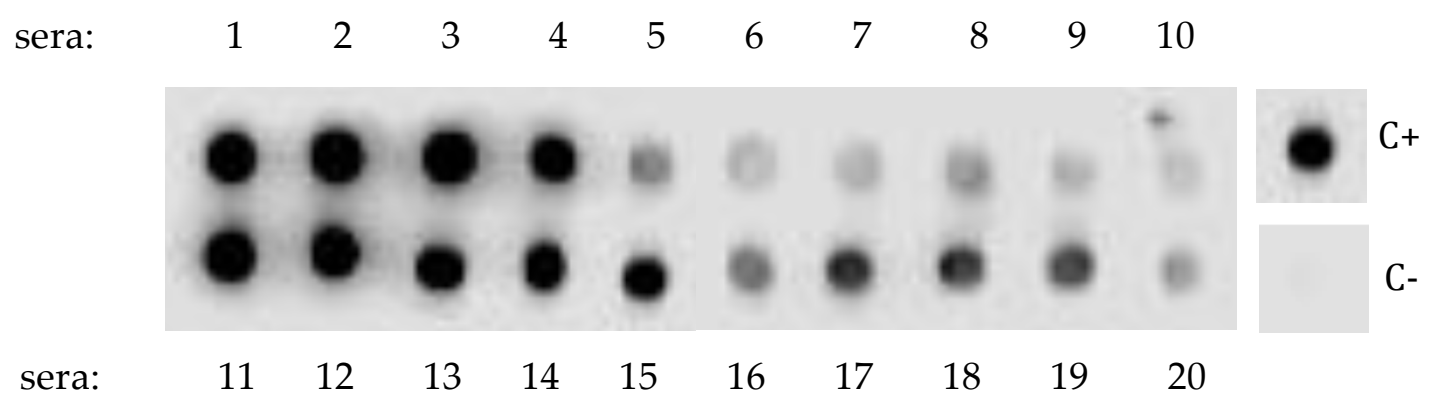

Figure 1. Dot-blot screening of the yellow mealworm protein extract (protein concentration of $15 \mathrm{mg} \mathrm{mL}^{-1}$ ) by 20 sera from shrimp-allergic patients, revealed with an anti-IgE second antibody. Data not shown for the single nonreactive serum \#21. Depending on the patient sera, the IgE cross-reacting antibodies interacted strongly (dark dot) or weakly (grey dot) with the immobilized protein extract. No data for sera from dust mite allergic patients were shown because most of them (11/13), gave negative results. $\mathrm{C}+$ and $\mathrm{C}-$ correspond to the positive and negative controls (first IgE antibody omitted) performed with a shrimp protein extract, respectively.

\subsection{Identification of IgE-Binding Cross-Reactive Allergens in the Yellow Mealworm Protein Extract}

Some of the IgE-binding protein fractions reavealed in Western blot experiments using different sera from patients allergic to shrimp corresponded to allergens previously identified in yellow mealworm protein extracts, e.g., tropomysosin, HSP (heat shock protein) $70, \alpha$-amylase, and arginine kinase (Figure 2) [36]. Many other mealworm allergens also interacted with the cross-reacting IgE-binding sera but have not been clearly identified by mass spectrometry. Other allergen proteins with low molecular weights have been identified at the bottom of the SDS-PAGE gels. They consist of predominantly hydrophobic proteins that are involved in the transportation of hydrophobic ligands like the apolipophorin-III (apoLp-III), often associated to the larval cuticle protein (LCP), which is abundantly represented in the yellow mealworm, and to a weaker IgE-binding signal corresponding to the $12 \mathrm{kDa}$ hemolymph protein (12 kDa-HLP).

Molecular modeling of these allergenic proteins (Figure 3) reveals the occurrence of hydrophobic cavities most probably adapted to the binding of hydrophobic ligands like fatty acids (apoLp-III) [48-50] or pheromone-like ligands (12 kDa-HLP) [51-59]. These newly identified insect allergens are reminscent of other proteins like the lipid transfer protein (LTP) allergens occurring in pollens and fruits, which also participate in the transport of hydrophobic compounds such as Pathogenesis-Related PR-14 members of the plant defense protein [66]. All of the newly identified insect allergens consist of ubiquitous proteins that share very conserved three-dimensional structures but rather poorly conserved amino acid sequences among the phylogenetically related insect species (Figures 4 and 5). In this respect, 
all of these ubiquitous allergens of different origins exhibit similar three-dimensional structures that are readily superposable even though their amino acid sequences are much less conserved (Figure 6).

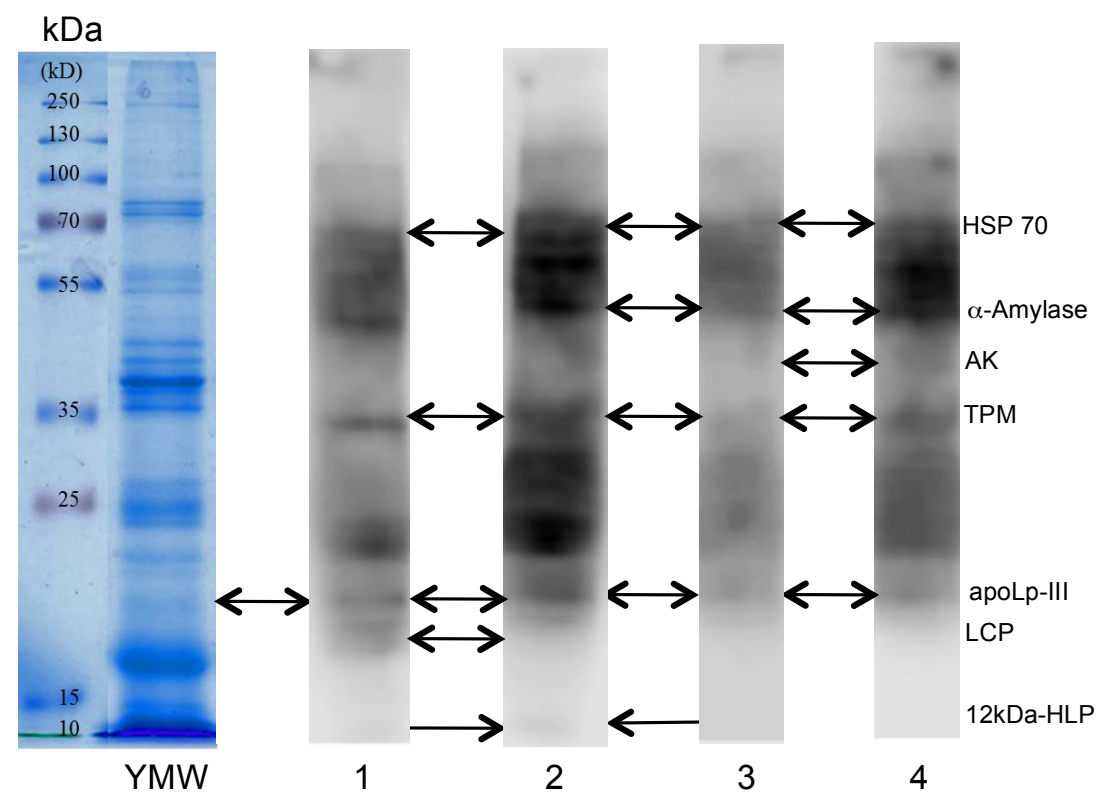

Figure 2. SDS-PAGE of the yellow mealworm (second line labelled, YMW). The first line corresponds to the electrophoretic migration of the MW markers (kDa). Lines 1, 2, 3, and 4 correspond to the Western blots of a yellow mealworm extract revealed by IgE-containing sera from different patients allergic to shrimp. The identified allergenic fractions HSP (heat shock protein) $70, \alpha$-amylase, arginine kinase (AK), tropomyosin (TPM), apolipophorin-III (apoLp-III), larval cuticle protein (LCP), and $12 \mathrm{kDa}$ hemolymph protein (12kDa-HLP (hemolymph protein)) of mealworm are indicated by arrows.

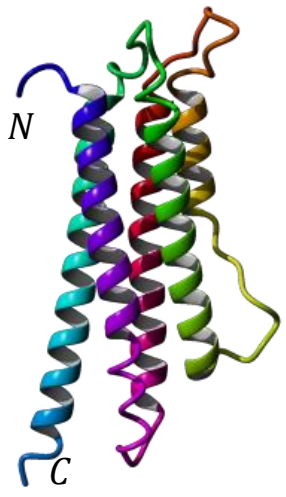

(A)

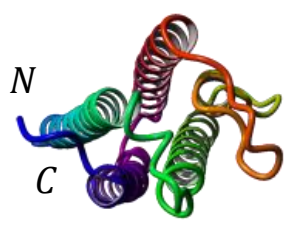

$\left(\mathbf{A}^{\prime}\right)$

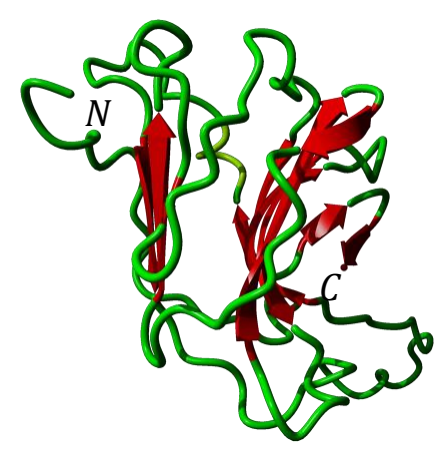

(B)

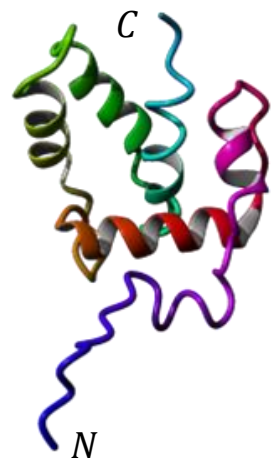

(C)

Figure 3. (A) Ribbon diagram of apolipophorin-III of Tenebrio molitor (sagital view). Alpha-helices numbered $\alpha 1-\alpha 5$ are differently colored. $N$ and $C$ correspond to the $N$ - and $C$-terminus of the polypeptide chain, respectively. (A') Ribbon diagram of apolipophorin-III of T. molitor: upper view showing the arrangemernt of $\alpha$-helices around a central hydrophobic pocket. (B) Ribbon diagram of the larval cuticlar protein (LCP) of T. molitor, built up from the association of two antiparallel bundles of $\beta$-sheet in a $\beta$-sandwich structure. (C) Ribbon diagram of the $12 \mathrm{kDa}$ hemolymph protein (12 kDa HLP) of T. molitor, built up from the association of six $\alpha$-helices around a central hydrophobic pocket. Alpha-helices are differently colored. 


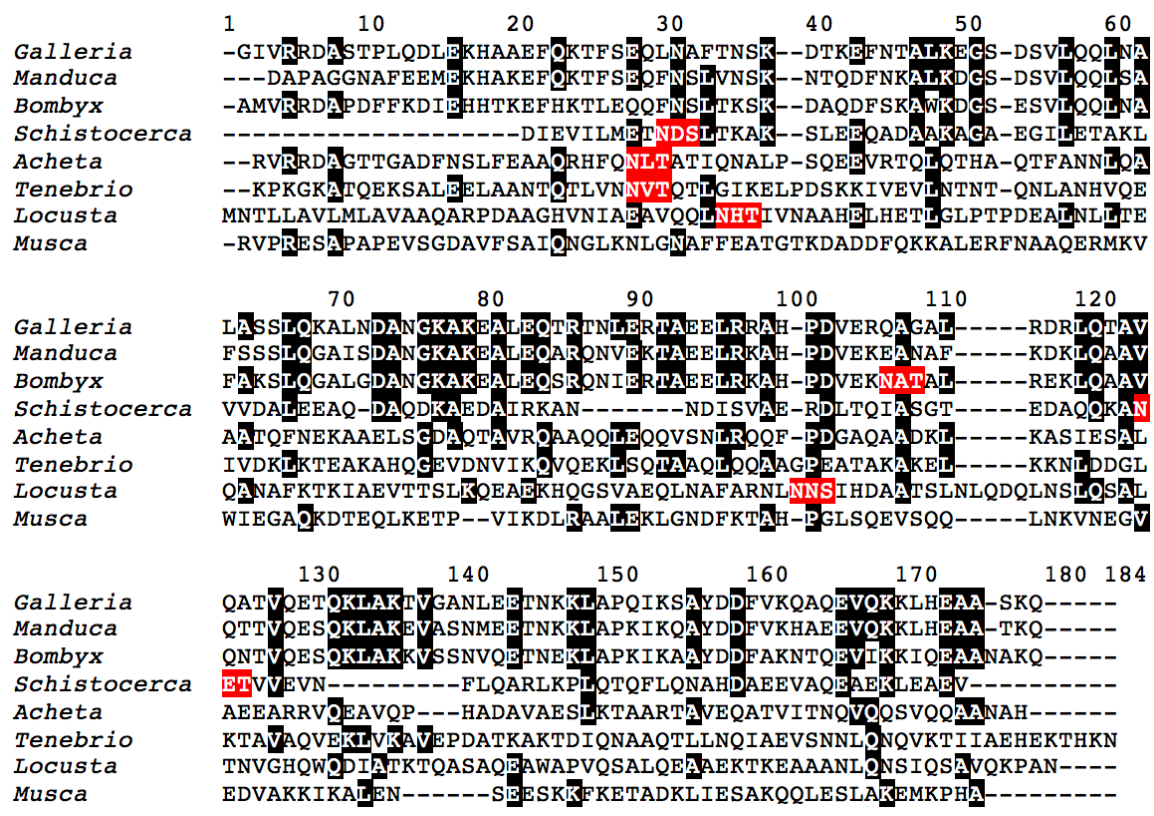

Figure 4. Multiple alignment of the apolipophorin-III protein from the edible insects Galleria mellonella, Manduca sexta, Bombyx mori, Schistocerca gregaria, Acheta domesticus, Tenebrio molitor, Locusta migratoria, and Musca domestica. Identical amino acid residues are in black boxed white letters. Putative N-glycosylation sites are colored red.

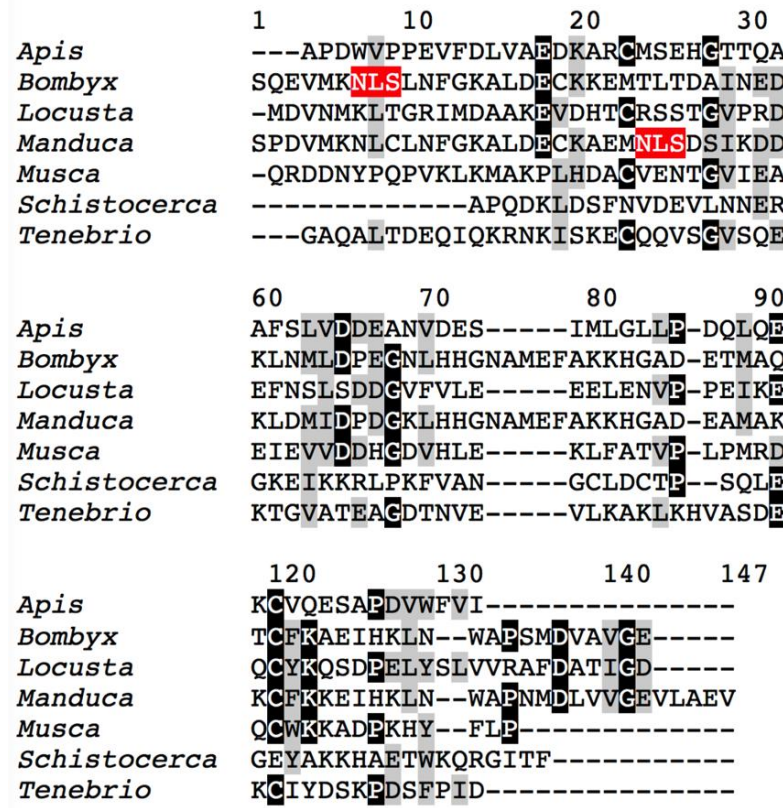

Figure 5. Multiple alignment of $12 \mathrm{kDa}$ HLP and OBP (odorant bindin proteins) from the edible insects Apis mellifera, Bombyx mori, Locusta migratoria, Manduca sexta, Musca domestica, Schistocerca gregaria, and Tenebrio molitor. Identical amino acids residues are in black boxed white letters whereas structurally homologous residues are grey boxed. Putative $N$-glycosylation sites are colored red. 


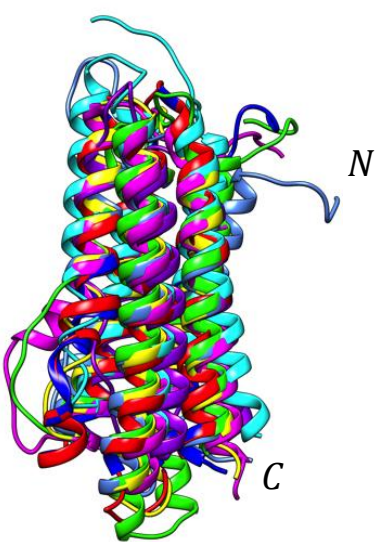

(A)

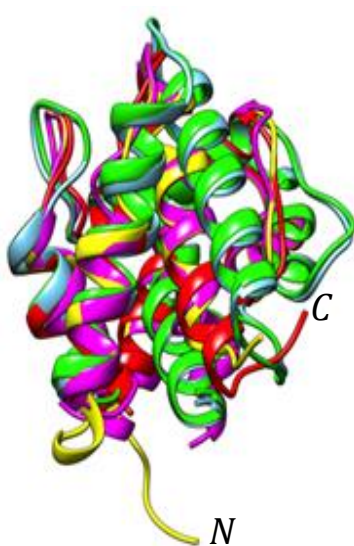

(B)

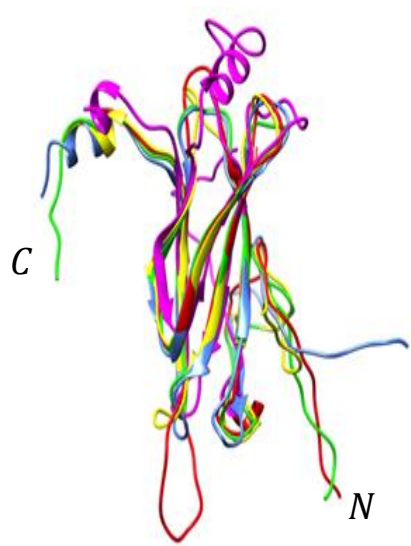

(C)

Figure 6. (A) Superposition of the differently colored three-dimensional models of apoLP-III of the edible insects Acheta domesticus (blue), Bombyx mori (green), Galleria mellonella (magenta), Locusta migratoria (yellow), Manduca sexta (deep blue), Musca domestica (cyan), Schistocerca gregaria (purple), and Tenebrio molitor (red). (B) Superposition of the differently colored three-dimensional models of $12 \mathrm{kDa}$ HLP and OBP of the edible insects Tenebrio molitor (red), Bombyx mori (blue), Manduca sexta (green), Onchorhynchus ferrugineus (magenta), and Apis mellifera (yellow). (C) Superposition of the differently colored three-dimensional models of cuticle protein of the edible insects Tenebrio molitor (red), Bombyx mori (green), Locusta migratoria (magenta), Musa domestica (yellow), and Tribolium castaneum (blue). $\mathrm{N}$ and $\mathrm{C}$ indicate the $\mathrm{N}$ - and $\mathrm{C}$-terminal ends of the polypeptide chains.

However, SDS-PAGE of the mealworm protein extract does not account for the extreme diversity in the soluble protein content of the mealworm. In this respect, the Coomassie blue-stained 2D SDS-PAGE gels offer a more relevant picture of the protein diversity occurring in the mealworm protein extract, which exhibits a number of protein spots occurring in the range between $\mathrm{pH} 3.0$ and $\mathrm{pH} 9.0$, with $\mathrm{MW}$ ranging from $10 \mathrm{kDa}$ up to $100 \mathrm{kDa}$ (Figure 7). This apparent diversity of the soluble protein content suggests that a huge number of soluble protein fractions occurring in the mealworm protein extract could behave as potential cross-recting IgE-binding allergens.

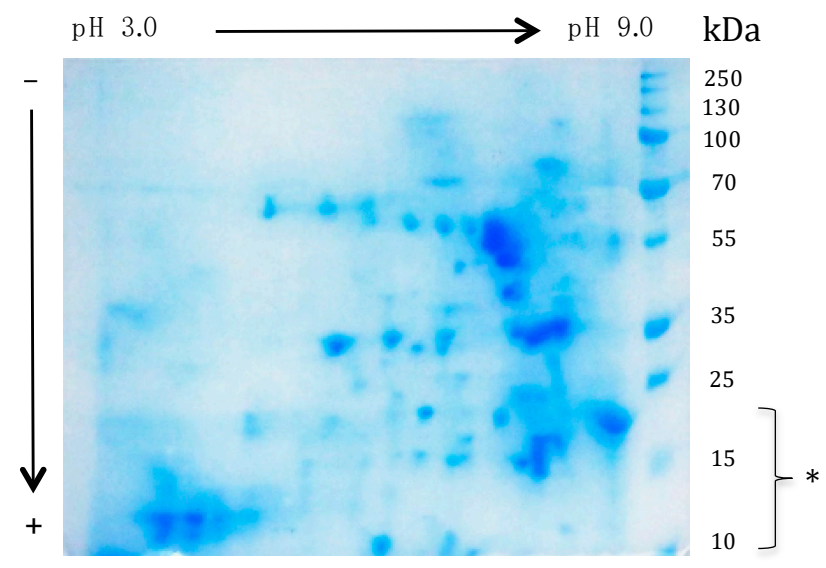

Figure 7. Bidimensional SDS-PAGE electrophoregram of the mealworm protein extract stained with Coomassie blue. A number of protein fractions with a MW in the range between $10 \mathrm{kDa}$ and $100 \mathrm{kDa}$, occur between $\mathrm{pH} 3.0$ and $\mathrm{pH}$ 9.0. Low MW protein fractions containing the apoLp-III, LCP and the $12 \mathrm{kDa}-\mathrm{HLP}$ allergens occur at the bottom of the gel $\left(^{*}\right)$.

\subsection{Characterization of the Potential Allergenic Protein Repertoire of the Mealworm Protein Extract}

A more sophisticated SDS-PAGE coupled to a mass spectrometry characterization allowed the identification of up to 106 distinct protein fractions in the mealworm protein extract (Table 1). 
Table 1. List of proteins identified in the yellow mealworm (Tenebrio molitor) protein extract. Proteins are ranked by decreasing scores. Proteins already identified as IgE-binding allergens from arthropods are in bold.

\begin{tabular}{|c|c|c|c|}
\hline Score: & Protein: & Score: & Protein: \\
\hline 2984.019 & $\alpha$-Myosin & 222.675 & $28 \mathrm{kDa}$ dessication stress protein \\
\hline 1214.674 & Aldehyde oxidase & 219.963 & Masquerade-like serine protease \\
\hline 1066.813 & Ca-transporting ATPase & 213.041 & 13 kDa hemolymph protein d \\
\hline 1025.416 & Actin 87E & 211.853 & Larval cuticle protein A3A \\
\hline \multirow[t]{2}{*}{940.811} & 86 kDa Early stage encapsulation & 211.417 & $12 \mathrm{kDa}$ hemolymph protein $\mathrm{c}$ \\
\hline & inducing protein & 210.607 & Myosin light chain alkali \\
\hline 895.841 & Tropomyosin 2 & 209.594 & Fructose-biphosphate aldolase \\
\hline 806.565 & Actin 5C & 209.332 & Serine proteinase \\
\hline 765.02 & Actinin $\alpha$ & 207.818 & Glutathione S-transferase \\
\hline 740.12 & Tubulin $\beta$ & 201.438 & $13 \mathrm{kDa}$ hemolymph protein $\mathrm{b}$ \\
\hline 664.062 & Prophenoloxidase & 198.188 & Vitellogenin receptor \\
\hline \multirow[t]{2}{*}{609.664} & Tropomyosin 1 & 190.799 & Troponin C \\
\hline & ATP synthase subunit $\beta$ & 189.968 & Calreticulin \\
\hline 504.441 & $\alpha$-Amylase & 187.099 & 4.5 LIM domains protein 5 \\
\hline 493.123 & Tubulin $\alpha$ & 184.454 & Cytochrome c2 \\
\hline 474.845 & Odorant binding protein OBP 14 & 179.106 & Nucleoside triphosphatase A \\
\hline 474.053 & Apolipophorin-III & 177.997 & Muscle-specific protein 20 \\
\hline 446.015 & Myosin heavy chain, non-muscle & 176.202 & Muscle LIM protein Mlp84B \\
\hline 445.547 & Arginine kinase & 171.809 & Enolase \\
\hline 439.842 & HSP 70 & 171.39 & Obstractor C2 \\
\hline 423.306 & Filamin-A & 168.27 & Protein disulfide-isomerase \\
\hline 395.328 & $12 \mathrm{kDa}$ hemolymph protein a & 164.625 & $13 \mathrm{kDa}$ hemolymph protein c \\
\hline 386.89 & Twitchin-like protein & 161.351 & Phosphoglycerate kinase \\
\hline 370.18 & Cockroach allergen-like protein & 159.53 & Chemosensory protein CSP12 \\
\hline 363.618 & Serpin 1 & 157.539 & $\alpha$-Spectrin \\
\hline 359.558 & ATP synthase subunit $\alpha$ & 157.443 & 14.3.3. $\zeta$ \\
\hline 340.168 & Hexamerin 2 & 155.443 & Glycogenin-1-like protein \\
\hline \multirow[t]{2}{*}{338.385} & Glyceraldehyde-3-phosphate & 151.351 & Phosphoglycerate kinase \\
\hline & dehydrogenase & 147.874 & Ferritin \\
\hline \multirow[t]{2}{*}{337.266} & 56 kDa Early stage encapsulation & 142.987 & Calumenin \\
\hline & inducing protein & 141.375 & Cathepsin L11 \\
\hline \multirow[t]{2}{*}{326.698} & Voltage-dependant anion-selective & 140.034 & Ribosomal protein S3 \\
\hline & channel protein & 132.912 & Nucleobindin-2 like protein \\
\hline 315.75 & Paramyosin long form & 130.118 & Trypsin \\
\hline 313.141 & Serpin 93 kDa & 129.432 & G protein-coupled receptor kinase 1 \\
\hline 296.596 & Larval cuticle protein A1A & 124.835 & THP isoform 84aa-XY \\
\hline 286.543 & Serpin 40 & 122.826 & Chitin deacetylase 1 \\
\hline 280.057 & Cathepsin F10 & 122.326 & Myosin regulatory light chain-2 \\
\hline 279.884 & $\alpha-1,4$-glucan phosphorylase & 122.024 & Malate dehydrogenase \\
\hline 278.386 & Larval cuticle protein $\mathrm{A} 2 \mathrm{~B}$ & 121.525 & Cuticular protein \\
\hline 278.215 & Troponin $\mathrm{T}$ & 118.956 & Chitinase \\
\hline 276.285 & Melanization-related protein & 116.322 & Glucose-6-phosphate isomerase \\
\hline 273.213 & Paramyosin short form & 99.944 & Carbonyl reductase 1 \\
\hline 269.133 & Peptidyl-prolyl cis-trans isomerase & 98.68 & Protein lethal/essential for life \\
\hline 260.731 & Apolipophorin-like protein & 96.268 & Transketolase-like protein 2 \\
\hline 259.533 & Myosin heavy chain, muscle & 89.762 & Multiple coagulation factor \\
\hline 259.092 & HSP 60 & & deficiency protein 2 \\
\hline 254.399 & V-type proton ATPase subunit $\beta$ & 87.931 & 605 ribosomal protein L31 \\
\hline 251.439 & Pyruvate kinase & 87.574 & ATP carrier protein \\
\hline 249.266 & Melanin-inhibiting protein & 87.104 & Lysosomal aspartic protease \\
\hline 247.353 & Serpin 48 & 78.888 & Aspartate aminotransferase \\
\hline 246.2 & Superoxide dismutase (Cu-Zn) & 76.674 & Elongation factor $1-\alpha$ \\
\hline 237.263 & $12 \mathrm{kDa}$ hemolymph protein $\mathrm{b}$ & 69.44 & Adenosylhomocysteinase \\
\hline 229.745 & RNA-binding protein squid-like & 59.528 & Muscular protein 20 \\
\hline 227.752 & Sarcalumenin & 34.596 & Reticulon-like protein \\
\hline
\end{tabular}


The identified proteins may be arbitrarily distributed in different categories according to their structure-function relationships, such as functional proteins (33 total, 31\%), enzymes (32 total, 30\%), structural proteins (18 total, 17\%), muscle proteins (17 total, $16 \%$ ), and others (6 total, $6 \%$ ) (Figure 8 ).

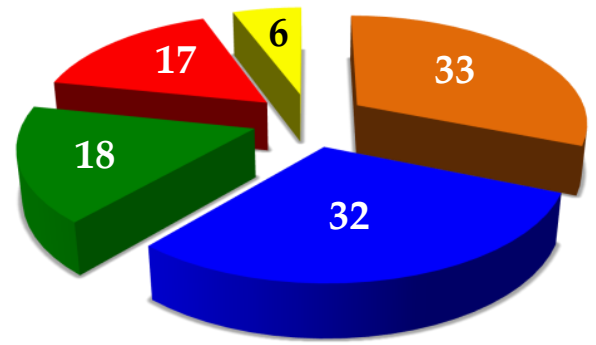

Figure 8. Distribution of the 106 proteins identified in the T. molitor extract, according to their potential functions: proteins with a functional role (33, orange), enzymes $(32$, blue), proteins with a structural function $(18$, green), muscle proteins $(17$, red), and proteins with other roles $(6$, yellow).

Most of the protein fractions belonging to the different structural and functional categories consist of cross-reacting IgE-binding allergens that have been previously identified in various insects and other groups of arthropods (dust mites, shrimps) and mollusks (mussels, oysters, snails) [67-76]. In this respect, a number of proteins involved in muscle contraction (actin, myosin) and others associated with muscle contraction (tropomyosin, troponin, actinin) occupy a large part of the allergen list. Allergens with enzymatic functions are also highly represented. It is noteworthy that the T. molitor list includes most of the allergens identified so far in both the American (Periplanta americana) and European (Blattella germanica) cockroaches.

\subsection{The Cross-Reacting Allergens of the Mealworm Protein Extract Are Functional in Degranulation Tests In Vitro}

In vitro degranulation experiments performed with different cross-reacting sera from shrimp-allergic patients as probes resulted in positive results for all of the assayed sera (Figure 9). However, depending on the shrimp patient sera, a large discrepancy was observed in the degranulation potency of the mealworm protein extract. These results suggest that the cross-reacting IgE-binding allergens of the mealworm protein extract are apparently functional and might trigger some allergenic response in previously sensitized people, e.g., in shrimp-allergic people. These degranulation data are in agreement with those previously reported for T. molitor [36,37].

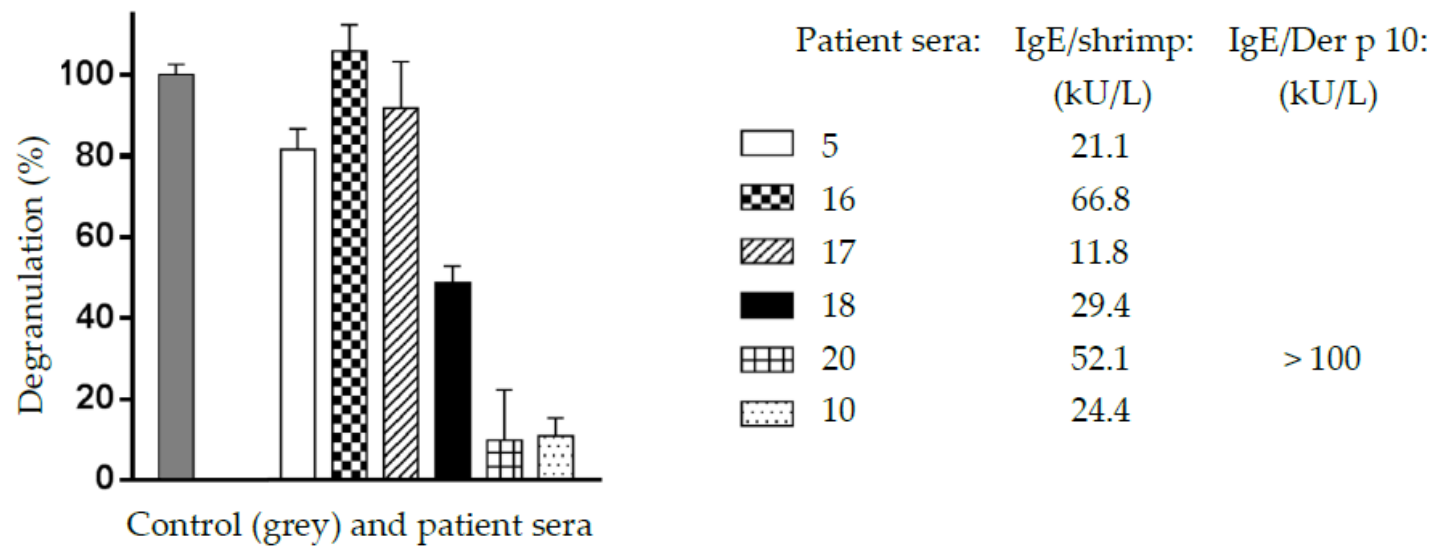

Figure 9. Degranulation potency, expressed as degranulation percentage (\%), caused by the mealworm protein extract, using six different sera $(5,16,17,18,20,10)$ from shrimp-allergic patients as IgE-binding cross-reacting allergens toward the mealworm allergenic proteins. A shrimp protein extract (grey histogram) was used as the $100 \%$ degranulation value (control C). Each value is the mean of six separate measurements. Values for specific IgE in sera 5, 16, 17, 18, 20, and 10, are indicated. 


\section{Discussion}

A few protein members in the mealworm protein extract were identified as new potential allergens, including the apolipophorin-III (apoL-III), the larval cuticular protein (LCP), and the $12 \mathrm{kDa}$ hemolymph protein (12 kDa HLP). Both apolipophorin-III and $12 \mathrm{kDa}$ HLP proteins participate in the binding and transport of hydrophobic ligands like fatty acids and derivatives for apoL-III and LCP or $12 \mathrm{kDa}$ HLP [48-59]. The $12 \mathrm{kDa}$ HLP consist of ubiquitous proteins closely related to the odorant binding proteins OBP widely distributed in insects, exhibiting conserved three-dimensional structures (Figure 6) even though their amino acid sequences are moderately conserved (Figure 5). However, the nature of small hydrophobic ligands they transport still remains a matter of debate. The larval cuticle proteins LCP represent a rather well conserved group of proteins possessing a chitin-binding domain. They play a key role in the deposition of the newly synthesized chitin chains forming the chitinous shell during the ecdysone-driven molt periods of insect larvae. They closely resemble some other pupal cuticle proteins, which also consist of a large hydrophilic central part with a $\beta$-fold flanked by two hydrophobic regions containing alanin-rich repetitive motifs [77].

Most, if not all, of the protein allergens of edible insects identified so far consist of ubiquitous proteins widely distributed in other arthropods including dust mites, crustaceans and other insects, mollusks, and nematods as well [78]. However, the number of proteins identified as insect allergens still remains very scarce compared to the diversity and complexity of their protein content. In this respect, some of the insect protein components, e.g., the hemolymph proteins for all the insect groups and muscle proteins for the flying insects, display an extreme diversity that reflects the successful adaptation of this group of animals to diverse ecological conditions during their evolution. Accordingly, it is expected that the still poorly understood allergen repertoire of edible insects will become progressively enriched by new proteins with allergenic properties. In fact, the difficulties in identifying and obtaining clinically well documented sera from insect allergic patients is a major breakthrough in the identification of new insect allergens. Even in countries where edible insects have traditionally been a significant part of the diet, only a few reports are available on the food allergic reactions attributable to eating crude or roasted insects [26]. In future years, the forthcoming introduction of insect flour as a protein-enriched supplement in the diet, will problably result in an increase of allergic manifestations among consumers. It will thus be possible to identify new allergenic proteins and, eventually, allergens specifically associated to some edible insect species.

Beside their potential negative impact on people suffering from shrimp allergy, mealworm protein flour should be used as a protein-rich source to supplement the diet for the treatment and care of severely undernourished people, owing to its excellent nutritional properties [79-82]. In addition, proteins from the yellow mealworm protein extract might bring some beneficial effect in mild to moderate hypertensive consumers, by providing angiotensin I-converting enzyme (ACE) inhibitory peptides upon digestive proteolysis. Like many other inhibitory peptides previously identified in the edible insect protein hydrolysates, ACE inhibitory peptides derived from Tenebrio molitor larva protein hydrolysate have been known for a long time $[83,84]$. Introducing some yellow mealworm protein flour into the diet should create a relevant source of ACE inhibitory peptides available for helping mildly hypertensive people to regulate their blood pressure. Yellow mealworm larvae also contain bioactive compounds with inhibitory activities for factor Xa and platelet aggregation [85]. Moreover, due to their antioxidant activities, introduction of edible insects in the diet could be beneficial for other oxidative-stress associated health disorders [86,87]. However, in addition to their beneficial properties, the sensory attributes of edible insects might be deeply investigated for improving the acceptance of edible insects in food production, especially by people of Western countries [88].

In spite of their beneficial properties, the incorporation of edible insects or insect proteins into the diet of shellfish allergic people still remains hazardous since the risk of an anaphylactic response can not be ruled out. In this respect, an appropriate labelling of edible insect packages and food product containing insect proteins is advisable to inform the consumers of such a potential risk. However, some recent reports demonstrate that appropriate food processing methods, e.g., thermal processing or 
enzymatic proteolysis, can drastically reduce the risk of cross-reactivity and allergenicity associated to edible insect proteins $[37,38,89]$.

Author Contributions: Investigation, C.P., E.V., A.M. and M.S.; Resources, A.B., L.G., F.B., H.B., J.B., O.B.-S. and C.A.; Writing — original draft, P.R.; Writing—review \& editing, P.R.

Funding: The Mass spectrometry analysis were supported in part by the Région Midi-Pyrénées, European funds (Fonds Européens de Développement Régional, FEDER), Toulouse Métropole, and by the French Ministry of Research with the Investissement d'Avenir Infrastructures Nationales en Biologie et Santé program (ProFI, Proteomics French Infrastructure project, ANR-10-INBS-08).

Acknowledgments: Rat leukemic cell line RBL SX38 was a gift from J.M. Wal (Laboratoire d'Immuno-Allergie Alimentaire, INRA, CEA, CEA de Saclay, Gif sur Yvette Cedex, France).

Conflicts of Interest: The authors declare no conflict of interest.

\section{Appendix A}

Table A1. Sera from patients allergic to shrimp (1a-21a) and dust mite (1b-13b), and specific IgE values.

\begin{tabular}{|c|c|c|c|}
\hline Seum: & Gender: & Shrimp Specific IgE $\left(\mathrm{kU} \cdot \mathrm{mL}^{-1}\right)$ & Der p 10 Specific IgE $\left(\mathrm{kU} \cdot \mathrm{mL}^{-1}\right)$ \\
\hline $1 \mathrm{a}$ & Female & 81.1 & \\
\hline $2 a$ & Female & 45.3 & \\
\hline $3 a$ & Female & 49.8 & \\
\hline $4 a$ & Male & 28.2 & $>100$ \\
\hline $5 a$ & Female & 21.1 & \\
\hline $6 a$ & Male & $>100$ & \\
\hline $7 \mathrm{a}$ & Female & 66.8 & \\
\hline $8 a$ & Male & $>100$ & \\
\hline $9 a$ & Male & 33.9 & \\
\hline $10 \mathrm{a}$ & Female & 24.4 & \\
\hline $11 \mathrm{a}$ & Male & 61.8 & \\
\hline $12 \mathrm{a}$ & Female & 54.8 & \\
\hline $13 a$ & Male & 11.2 & 40.8 \\
\hline $14 a$ & Female & $>100$ & \\
\hline $15 a$ & Female & 18.8 & \\
\hline $16 \mathrm{a}$ & Female & 66.8 & \\
\hline $17 \mathrm{a}$ & Male & 11.8 & \\
\hline $18 \mathrm{a}$ & Male & 29.4 & \\
\hline $19 a$ & Female & $>100$ & \\
\hline $20 a$ & Male & 52.1 & $>100$ \\
\hline $21 \mathrm{a}$ & Female & 10.2 & \\
\hline $1 b$ & Male & & $>100$ \\
\hline $2 b$ & Female & & $>100$ \\
\hline $3 b$ & Female & & $>100$ \\
\hline $4 b$ & Female & 17.0 & $>100$ \\
\hline $5 b$ & Female & & $>100$ \\
\hline $6 b$ & Female & & $>100$ \\
\hline $7 \mathrm{~b}$ & Female & & $>100$ \\
\hline $8 b$ & Male & & $>100$ \\
\hline $9 b$ & Male & 1.4 & $>100$ \\
\hline $10 \mathrm{~b}$ & Female & 27.3 & $>100$ \\
\hline $11 \mathrm{~b}$ & Male & 2.4 & 84.6 \\
\hline $12 b$ & Female & 0.1 & 13.1 \\
\hline $13 b$ & Male & & $>100$ \\
\hline
\end{tabular}

\section{References}

1. DeFoliart, G.; Nakagaki, B.; Sunde, M. Protein quality of the house cricket Acheta domestica when fed to broiler chicks. Poult. Sci. 1987, 66, 1367-1371. 
2. Oonincx, D.G.; de Boer, I.J. Environmental impact of the production of mealworms as a protein source for humans-A life cycle assessment. PLoS ONE 2012, 7, e51145. [CrossRef] [PubMed]

3. Rumpold, B.A.; Schluter, O.K. Potential and challenges of insects as an innovative source for food and feed production. Innov. Food Sci. Emerg. Technol. 2013, 17, 1-11. [CrossRef]

4. Rumpold, B.A.; Schluter, O.K. Nutritional composition and safety aspects of edible insects. Mol. Nutr. Food Res. 2013, 57, 802-823. [CrossRef] [PubMed]

5. Li, L.; Zhao, Z.; Liu, H. Feasibility of feeding yellow mealworm (Tenebrio molitor L.) in bioregenerative life support systems as a source of animal protein for humans. Acta Astron. 2013, 92, 103-109. [CrossRef]

6. Oonincx, D.G.; van Broekhoven, S.; van Huis, A.; van Loon, J.J. Feed conversion, survival and development, and composition of four insect species on diets composed of food by-products. PLOS ONE 2015, 10, e0144601. [CrossRef]

7. Van Huis, A. Edible insects are the future? Proc. Nutr. Soc. 2016, 75, 294-305. [CrossRef]

8. Feng, Y.; Chen, X.M.; Zhao, M.; He, Z.; Sun, L.; Wang, C.Y.; Ding, W.F. Edible insects in China: Utilization and prospects. Insect Sci. 2017. [CrossRef]

9. Van Broekhoven, S.; Oonincx, D.G.; van Huis, A.; van Loon, J.J. Growth performance and feed conversion efficiency of three edible mealworm species (Coleoptera: Tenebrionidae) on diets composed of organic by-products. J. Insect Physiol. 2015, 73, 1-10. [CrossRef]

10. Bußler, S.; Rumpold, B.A.; Jander, E.; Rawel, H.M.; Schlüter, O.K. Recovery and techno-functionality of flours and proteins from two edible insects: Meal worm (Tenebrio molitor) and black soldier fly (Hermetia illucens) larvae. Helivon 2016, 2, e00218. [CrossRef]

11. Janssen, R.H.; Vincken, J.P.; van den Broek, L.A.; Fogliano, V.; Lakemond, C.M. Nitrogen-to-protein conversion factors for thee edible insects: Tenebrio molitor, Alphitobius diaperinus, and Hermetia illucens. J. Agric. Food Chem. 2017, 65, 2275-2278. [CrossRef] [PubMed]

12. Belluco, S.; Losasso, C.; Maggioletti, M.; Alonzi, C.C.; Paoletti, M.G.; Ricci, A. Edible insects in a food safety and nutritional perspective: A critical review. Compr. Rev. Food Sci. Food Saf. 2013, 12, 296-313. [CrossRef]

13. Van Huis, A.; Van Itterbeeck, J.; Klunder, H.; Mertens, E.; Halloran, A.; Muir, G.; Vantomme, P. Edible Insects: Future Prospects for Food and Feed Security; FAO Forestry Paper 171; Food and Agriculture Organization of the United Nations: Rome, Italy, 2013; ISBN 978-92-5-107595-1.

14. Charlton, A.J.; Dickinson, M.; Wakefield, M.E.; Fitches, E.; Kenis, M.; Han, R.; Zhu, F.; Kone, N.; Grant, M.; Devic, E.; et al. Exploring the chemical safety of fly larvae as a source of protein for animal feed. J. Insect Food Feed 2015, 1, 7-16. [CrossRef]

15. Schlüter, O.; Rumpold, B.; Holzhauser, T.; Roth, A.; Vogel, R.F.; Quasigroch, W.; Vogel, S.; Heinz, V.; Jäger, H.; Bandick, N.; et al. Safety aspects of the production of foods and food ingredients from insects. Mol. Nutr. Food Res. 2017, 61. [CrossRef] [PubMed]

16. Testa, M.; Stillo, L.; Maffei, G.; Andriolo, V.; Gardois, P.; Zotti, C.M. Ugly but tasty: A systematic review of possible human and animal health risks related to entomophagy. Crit. Rev. Food Nutr. 2017, 57, 3747-3759. [CrossRef]

17. Bernton, H.S.; Brown, H. Insects as potential sources of ingestant allergens. Ann. Allergy 1967, 25, 381-387.

18. Phillips, J.; Burkholder, W. Allergies related to food insect production and consumption. Food Insect Newsl. 1995, 8, 1-2.

19. Van der Brempt, X.; Moneret-Vautrin, D.A. The allergic risk of Tenebrio molitor for human consumption (article in French). Rev. Fr. Allergol. 2014, 54, 34-36. [CrossRef]

20. Barre, A.; Caze-Subra, S.; Gironde, C.; Bienvenu, F.; Bienvenu, J.; Rougé, P. Entomophagy and the risk of allergy (article in French). Rev. Fr. Allergol. 2014, 54, 315-321. [CrossRef]

21. Van der Brempt, X.; Beaudoin, E.; Lavaud, F. Is eating insects risky for allergic patients? Rev. Fr. Allergol. 2016, 56, 186-188. (In French) [CrossRef]

22. Ribeiro, J.C.; Cunha, L.M.; Sousa-Pinto, B.; Fonseca, J. Allergic risks of consuming edible insects: A systematic review. Mol. Nutr. Food Res. 2018, 62. [CrossRef] [PubMed]

23. Teranishi, H.; Kawai, K.; Murakami, G.; Miyao, M.; Kasuya, M. Occupational allergy to adult chironomid midges among environmental researchers. Jpn. Int. Arch. Allergy Immunol. 1995, 106, 271-277. [CrossRef] [PubMed]

24. Freye, H.B.; Esch, R.E.; Litwin, C.M.; Sorkin, L. Anaphylaxis to the ingestion and inhalation of Tenebrio molitor (mealworm) and Zophobas morio (superworm). Allergy Asthma Proc. 1996, 17, 215-219. [CrossRef] [PubMed] 
25. Aldunate, M.T.; Echechipía, S.; Gómez, B.; García, B.E.; Olaguibel, J.M.; Rodríguez, A.; Moneo, I.; Tabat, A.I. Chironomids and other causes of fish food allergy. Allergol. Immunol. Clin. 1999, 14, 140-145.

26. Ji, K.; Chen, J.; Li, M.; Liu, Z.; Wang, C.; Zhan, Z.; Wu, X.; Xia, Q. Anaphylactic shock and lethal anaphylaxis caused by food consumption in China. Trends Food Sci. Technol. 2009, 20, 227-231. [CrossRef]

27. Choi, G.S.; Shin, Y.; Kim, J.E.; Ye, Y.M.; Park, H.S. Five cases of food allergy to vegetable worm (Cordyceps sinensis) showing cross-reactivity with silkworm pupæ. Allergy 2010, 65, 1196-1197. [CrossRef]

28. Okezie, O.A.; Kgomotso, K.K.; Letswiti, M.M. Mopane worm allergy in a 36-year-old woman: A case report. J. Med. Case Rep. 2010, 4, 42. [CrossRef]

29. Yew, K.L.; Kok, V.S.L. Exotic food anaphylaxis and the broken heart: Sago worm and Takotsubo cardiomyopathy. Med. J. Malays. 2012, 5, 540-541.

30. Pener, M.P. Allergy to crickets: A review. J. Orthoptera Res. 2016, 25, 91-95. [CrossRef]

31. Santos, A.B.R.; Chapman, M.D.; Aalberse, R.C.; Vailes, L.D.; Ferriani, V.P.L.; Oliver, C.; Rizzo, M.C.; Naspitz, C.K.; Arruda, L.K. Cockroach allergens and asthma in Brazil: Identification of tropomyosin as a major allergen with potential cross-reactivity with mite and shrimp allergens. J. Allergy Clin. Immunol. 1999, 104, 329-337. [CrossRef]

32. Reese, G.; Ayuso, R.; Lehrer, S.B. Tropomyosin: An invertebrate pan-allergen. Int. Arch. Allergy Immunol. 1999, 119, 247-258. [CrossRef] [PubMed]

33. Galindo, P.A.; Lombardero, M.; Borja, J.E.G.; Feo, F.; Barber, D.; García, R. A new arthropod panallergen? Allergy 2001, 56, 195-197. [CrossRef] [PubMed]

34. Shafique, R.H.; Inam, M.; Ismail, M.; Chaudhary, F.R. Group 10 allergens (tropomyosins) from house-dust mites may cause covariation of sensitization to allergens from other invertebrates. Allergy Rhinol. 2010, 3, e74-e90. [CrossRef] [PubMed]

35. Binder, M.; Mahler, V.; Hayek, B.; Sperr, W.R.; Schöller, M.; Prozell, S.; Wiedermann, G.; Valent, P.; Valenta, R.; Duchêne, M. Molecular and immunological characterization of arginine kinase from the Indianmeal moth, Plodia interpunctella, a novel cross-reactive invertebrate pan-allergen. J. Immunol. 2001, 167, 5470-5477. [CrossRef]

36. Verhoeckx, K.C.M.; van Broekhoven, S.; den Hartog-Jager, C.F.; Gaspari, M.; de Jong, G.A.H.; Wichers, H.J.; van Hoffen, E.; Houben, G.F.; Knulst, A.C. House dust mite (Der p 10) and crustacean allergic patients may react to food containing yellow mealworm proteins. Food Chem. Toxicol. 2014, 65, 364-373. [CrossRef]

37. Broekman, H.; Knulst, A.; den Hartog Jager, S.; Monteleone, F.; Gaspari, M.; de Jong, G.; Houben, G.; Verhoeckx, K. Effect of thermal processing on mealworm allergenicity. Mol. Nutr. Food Res. 2015, 59, 1855-1864. [CrossRef]

38. Van Broekhoven, S.; Bastiaan-Net, S.; de Jong, N.W.; Wichers, H.J. Influence of processing and in vitro digestion on the allergic cross-reactivity of three mealworm species. Food Chem. 2016, 196, 1075-1083. [CrossRef]

39. Debaugnies, F.; Francis, F.; Delporte, C.; Doyen, V.; Lendent, C.; Mairesse, M.; Van Antwerpen, P.; Corraza, F. Identification de $1^{\prime} \alpha$-amylase comme allergène du ver de farine chez des patients professionnellement exposés. Rev. Fr. Allergol. 2016, 56, 281. (In French) [CrossRef]

40. Srinroch, C.; Srisomsap, C.; Chokchaichamnankit, D.; Punyarit, P.; Phiriyangkul, P. Identification of novel allergen in edible insect, Gryllus bimaculatus and its cross-reactivity with Macrobrachium spp. allergens. Food Chem. 2015, 184, 160-166. [CrossRef]

41. Just, N.; Lièvre, K.; Lallemand, K.; Leduc, V. Implication de l'hexamérine dans un cas d'allergie aux larves de mouches. Rev. Fr. Allergol. 2012, 52, 258. (In French) [CrossRef]

42. De Gier, S.; Verhoeckx, K. Insect (food) allergy and allergens. Mol. Immunol. 2018, 100, 82-106. [CrossRef] [PubMed]

43. Smith, P.K.; Krohn, R.I.; Hermanson, G.T.; Mallia, A.K.; Gartner, F.H.; Provenzano, M.D.; Fujimoto, E.K.; Goeke, N.M.; Olson, B.J.; Klenk, D.C. Measurement of protein using bicinchoninic acid. Anal. Biochem. 1985, 150, 76-85. [CrossRef]

44. Laemmli, U.K. Cleavage of structural proteins during the assembly of the head of bacteriophage T4. Nature 1970, 227, 680-685. [CrossRef] [PubMed]

45. Wiegand, T.W.; Williams, P.B.; Dreskin, S.C.; Jouvin, M.H.; Kinet, J.P.; Tasset, D. High-affinity oligonucleotide ligands to human IgE inhibit binding to Fc epsilon receptor I. J. Immunol. 1996, 157, 221-230. 
46. Thompson, J.D.; Gibson, T.J.; Plewniak, F.; Jeanmougin, F.; Higgins, D.G. The CLUSTAL-X windows interface: Flexible strategies for multiple sequence alignment aided by quality analysis tool. Nucleic Acids Res. 1999, 15, 4876-4882.

47. Risler, J.-L.; Delorme, M.O.; Delacroix, H.; Henaut, A. Amino acid substitutions in structurally related proteins. A pattern recognition approach. Determination of a new an efficient scoring matrix. J. Mol. Biol. 1998, 204, 1019-1029. [CrossRef]

48. Breiter, D.R.; Kanost, M.R.; Benning, M.M.; Wesenberg, G.; Law, J.H.; Wells, M.A.; Rayment, I.; Holden, H.M. Molecular structure of an aloplipoprotein determined at 2.5- $\AA$ resolution. Biochemistry 1991, 30, 603-608. [CrossRef]

49. Fan, D.; Zheng, Y.; Yang, D.; Wang, J. NMR solution structure and dynamics of an exchanh-geable apolipoprotein, Locusta migratoria apolipophorin III. J. Biol. Chem. 2003, 278, 21212-21220. [CrossRef]

50. Wang, J.; Sykes, B.D.; Ryan, R.O. Structural basis for the conformational adaptability of apolipophorin III, a helix-bundle exchangeable apolipoprotein. Proc. Natl. Acad. Sci. USA 2002, 99, 1188-1193. [CrossRef]

51. Rothemund, S.; Liou, Y.C.; Davies, P.L.; Krause, E.; Sönnichsen, F.D. A new class of hexahelical insect proteins revealed as putative carriers of small hydrophobic ligands. Structure 1999, 7, 1325-1332. [CrossRef]

52. Krieger, E.; Koraimann, G.; Vriend, G. Increasing the precision of comparative models with YASARA NOVA-A self-parameterizing force field. Proteins 2002, 47, 393-402. [CrossRef] [PubMed]

53. Spinelli, S.; Lagarde, A.; Iovinella, P.; Legrand, P.; Tegoni, M.; Pelosi, P.; Cambillau, C. Crystal structure of Apis mellifera OBP14, a C-minus odorant-binding protein, and its complexes with odorant molecules. Insect Biochem. Mol. Biol. 2012, 42, 41-50. [CrossRef] [PubMed]

54. Lagarde, A.; Spinelli, S.; Tegoni, M.; He, X.; Field, L.; Zhou, J.J.; Cambillau, C. The crystal structure of odorant binding protein 7 from Anopheles gambiae exhibits an outstanding adaptability of its binding site. J. Mol. Biol. 2011, 414, 401-412. [CrossRef] [PubMed]

55. Di Luccio, E.; Ishjida, Y.; Leal, W.S.; Wilson, D.K. Crystallographic observation of pH-induced conformational changes in the Amyelois transitella pheromone-binding protein AtraPBP1. PLoS ONE 2013, 8, e53840. [CrossRef]

56. Damberger, F.F.; Ishida, Y.; Leal, W.S.; Wüthrich, K. Structural basis of ligand binding and release in insect pheromone-binding protein: NMR structure of Antheraea polyphemus PBP1 at pH 450. J. Mol. Biol. 2007, 373, 811-819. [CrossRef]

57. Zhou, J.J.; Robertson, G.; He, X.; Dufour, S.; Hooper, A.M.; Pickett, J.A.; Keep, N.H.; Field, L.M. Characterisation of Bombyx mori odorant-binding proteins reveals that a general odorant-binding protein discriminates between sex pheromone components. J. Mol. Biol. 2009, 389, 529-545. [CrossRef]

58. Campanacci, V.; Lartigue, A.; Hällberg, B.M.; Jones, T.A.; Giudici-Orticoni, M.T.; Tegoni, M.; Cambillau, C. Moth chemosensory protein exhibits drastic conformational changes and cooperativity on ligand binding. Proc. Natl. Acad. Sci. USA 2003, 100, 5069-5074. [CrossRef]

59. Jansen, S.; Chmelik, J.; Zidek, L.; Padrta, P.; Novák, P.; Zdráhal, Z.; Picimbon, J.F.; Löfstedt, C.; Sklenár, V. Structure of Bombyx mori chemosensory protein 1 in solution. Arch. Insect Biochem. Physiol. 2007, 66, 135-145. [CrossRef]

60. Laskowski, R.A.; MacArthur, M.W.; Moss, D.S.; Thornton, J.M. PROCHECK: A program to check the stereochemistry of protein structures. J. Appl. Cryst. 1993, 26, 283-291. [CrossRef]

61. Melo, F.; Feytmans, E. Assessing protein structures with a non-local atomic interaction energy. J. Mol. Biol. 1998, 277, 1141-1152. [CrossRef]

62. Benkert, P.; Biasini, M.; Schwede, T. Toward the estimation of the absolute quality of individual protein structure models. Bioinformatics 2011, 27, 343-350. [CrossRef] [PubMed]

63. Arnold, K.; Bordoli, L.; Kopp, J.; Schwede, T. The SWISS-MODEL workspace: A web-based environment for protein structure homology modelling. Bioinformatics 2006, 22, 195-201. [CrossRef] [PubMed]

64. Glaser, F.; Pupko, T.; Bell, R.E.; Bechor, D.; Martz, E.; Ben-Tal, N. ConSurf: Identification of functional regions in proteins by surface-mapping of phylogenetic informations. Bioinformatics 2003, 19, 163-164. [CrossRef]

65. Pettersen, E.F.; Goddard, T.D.; Huang, C.C.; Couch, G.S.; Greenblatt, D.M.; Meng, E.C.; Ferrin, T.E. UCSF Chimera-A visualization system for exploratory research and analysis. J. Comput. Chem. 2004, 25, 1605-1612. [CrossRef] [PubMed] 
66. Radauer, C.; Bublin, M.; Wagner, S.; Mari, A.; Breiteneder, H. Allergens are distributed into few protein families and possess a restricted number of biochemical functions. J. Allergy Clin. Immunol. 2008, 121, 847-852. [CrossRef] [PubMed]

67. Sánchez-Borges, M.; Capriles-Hulett, A.; Fernández-Caldas, E.; Suárez-Chacón, R.; Caballero, F.; Castillo, S.; Sotillo, E. Mite-contaminated foods as a cause of anaphylaxis. J. Allergy Clin. Immunol. 1997, 99, 738-743. [CrossRef]

68. Sánchez-Borges, M.; Suárez-Chacón, R.; Capriles-Hulett, A.; Caballero-Fonseca, F.; Iraola, V.; Fernández-Caldas, E. Anaphylaxis from ingestion of mites: Pancake anaphylaxis. J. Allergy Clin. Immunol. 2013, 131, 31-35. [CrossRef] [PubMed]

69. Huang, Y.Y.; Liu, G.M.; Cai, Q.F.; Weng, W.Y.; Maleki, S.J.; Su, W.J.; Cao, M.J. Stability of major allergen tropomyosin and other food proteins of mud crab (Scylla serrata) by in vitro gastrointestinal digestion. Food. Chem. Toxicol. 2010, 48, 1196-1201. [CrossRef] [PubMed]

70. Sahabudin, S.; Misnan, R.; Yadzir, Z.H.; Mohamad, J.; Abdullah, N.; Bakhtiar, F.; Murad, S. Identification of major and minor allergens of black tiger prawn (Penaeus monodon) and king prawn (Penaeus latisulcatus). Malays. J. Med. Sci. 2011, 18, 2732.

71. Yadzir, Z.H.M.; Misnan, R.; Abdullah, N.; Bakhtiar, F.; Arip, M.; Murad, S. Identification of the major allergen of Macrobrachium rosenbergii (giant freshwater prawn). Asian Pac. J. Trop. Biomed. 2012, 2, 50-54. [CrossRef]

72. Rosmilah, M.; Shahnaz, M.; Zailatul, H.M.Y.; Noormalin, A.; Normilah, I. Identification of tropomyosin and arginine kinase as major allergens of Portunus pelagicus (blue swimming crab). Trop. Biomed. 2012, 29, 467-478. [PubMed]

73. Misnan, R.; Murad, S.; Yadzir, Z.H.; Abdullah, N. Identification of the major allergens of Charybdis feriatus (red crab) and its cross-reactivity with Portunus pelagicus (blue crab). Asian Pac. J. Allergy Immunol. 2012, 30, 285-293. [PubMed]

74. Meseguer Arce, J.; Sánchez-Guerrero Villajos, I.M.; Iraola, V.; Carnés, J.; Fernández Caldas, E. Occupational allergy to aquarium fish food: Red midge larva, freshwater shrimp, and earthworm. A clinical and immunological study. J. Investig. Allergol. Clin. Immunol. 2013, 23, 462-470.

75. Yadzir, Z.H.; Misnan, R.; Bakhtiar, F.; Abdullah, N.; Murad, S. Tropomyosin, the major tropical oyster Crassostrea belcheri allergen and effect of cooking on its allergenicity. Allergy Asthma Clin. Immunol. 2015, 11, 30. [CrossRef] [PubMed]

76. Broekman, H.; Verhoeckx, K.C.; den Hartog Jager, C.F.; Kruizinga, A.G.; Pronk-Kleinjan, M.; Remington, B.C.; Bruijnzeel-Koomen, C.A.; Houben, G.F.; Knulst, A.C. Majority of shrimp-allergic patients are allergic to mealworm. Allergy Clin Immunol. 2016, 137, 1261-1263. [CrossRef] [PubMed]

77. Rondot, I.; Quennedey, B.; Delachambre, J. Structure, organization and expression of two clustered cuticle protein genes during the metamorphosis of an insect, Tenebrio molitor. Eur. J. Biochem. 1998, 254, 304-312. [CrossRef]

78. Rougé, P.; Barre, A. Allergy to edible insects: A computational identification of the IgE-binding cross-reacting allergen repertoire of edible insects. In Future Foods; Mikkola, H., Ed.; INTECH: Croatia, Balkans, 2017; Volume 4, pp. 71-88.

79. Nadeau, L.; Nadeau, I.; Franklin, F.; Dunkel, F. The potential for entomophagy to address undernutrition. Ecol. Food Nutr. 2015, 54, 200-208. [CrossRef]

80. Barennes, H.; Phimmasane, M.; Rajaonarivo, C. Insect consumption to address undernutrition, a national survey of the prevalence of insect consumption among adults and vendors in Laos. PLOS ONE 2015, 10, e0136458. [CrossRef]

81. Payne, C.L.; Scarborough, P.; Rayner, M.; Nonaka, K. Are edible insects more or less 'healthy' than commonly consumed meats? A comparison using two nutrient profiling models developed to combat over- and undernutrition. Eur. J. Clin. Nutr. 2016, 70, 285-291. [CrossRef]

82. Laar, A.; Kotoh, A.; Parker, M.; Milani, P.; Tawiah, C.; Soor, S.; Anankware, J.P.; Kalra, N.; Manu, G.; Tandoh, A.; et al. An exploration of edible palm weevil larvae (akokono) as a source of nutrition and livelihood: Perspectives from Ghanaian stakeholders. Food Nutr. Bull. 2017, 38, 455-467. [CrossRef]

83. Dai, C.; Ma, H.; Luo, L.; Yin, X. Angiotensin I-converting enzyme (ACE) inhibitory peptide derived from Tenebrio molitor (L.) larva protein hydrolysate. Eur. Food Res. Technol. 2013, 236, 681-689. [CrossRef] 
84. Cito, A.; Dreassi, E.; Frosinini, R.; Zanfini, A.; Pianigiani, C.; Botta, M.; Francardi, V. The potential beneficial effects of Tenebrio molitor (Coleoptera: Tenebrionidae) and Galleria mellonella (Lepidoptera: Pyralidae) on human health. Redia 2017, 100, 125-133.

85. Lee, W.; Kim, M.A.; Park, I.; Hwang, J.S.; Na, M.; Bae, J.S. Novel direct factor Xa inhibitory compounds from Tenebrio molitor with anti-platelet aggregation activity. Food Chem. Toxicol. 2017, 109, 19-27. [CrossRef]

86. Dutta, P.; Dey, T.; Manna, P.; Kalita, J. Antioxidant potential of Vespa affinis L., a traditional edible insect species of North East India. PLoS ONE 2016, 11, e0156107. [CrossRef]

87. Dutta, P.; Dey, T.; Dihingia, A.; Manna, P.; Kalita, J. Antioxidant and glucose metabolizing potential of edible insect, Brachytrupes orientalis via modulating Nrf2/AMPK/GLUT4 signaling pathway. Biomed. Pharmacother. 2017, 95, 556-563. [CrossRef] [PubMed]

88. Wendin, K.; Olsson, V.; Langton, M. Mealworms as food ingredient-Sensory investigation of a model system. Foods 2019, 8, 319. [CrossRef] [PubMed]

89. Pali-Schöll, I.; Meinlschmidt, P.; Larenas-Linnemann, D.; Purschke, B.; Hofstetter, G.; Rodríguez-Monroy, F.A.; Einhorn, L.; Mothes-Luksch, N.; Jensen-Jarolim, E.; Jäger, H. Edible insects: Cross-recognition of IgE from crustacean- and house dust mite allergic patients, and reduction of allergenicity by food processing. World Allergy Organ. J. 2019, 12, 100006. [CrossRef]

(C) 2019 by the authors. Licensee MDPI, Basel, Switzerland. This article is an open access article distributed under the terms and conditions of the Creative Commons Attribution (CC BY) license (http://creativecommons.org/licenses/by/4.0/). 